\title{
COMMISSIONS OF INQUIRY AS A RESPONSE TO CRISIS: THE ROLE OF THE JALI COMMISSION IN CREATING PUBLIC AWARENESS OF CORRUPTION (PART 1)
}

\author{
Stephen Allister Peté \\ BA LLB LLM M Phil PhD \\ Associate Professor of Law, School of Law, \\ University of KwaZulu-Natal
}

\section{SUMMARY}

When the government of a liberal constitutional democracy is confronted by some or other existential crisis that threatens a major institution of state or the very foundations of the democracy itself, it will often appoint a high-level judicial commission of inquiry as part of its response to the crisis. South Africa is no exception to this tendency, as is evidenced in recent years by the appointment of no fewer than four such commissions in response to a series of crises related to ongoing corruption within state institutions - commonly referred to by ordinary South Africans as "state capture". This has raised questions as to the alleged benefits of such commissions when viewed in relation to their considerable costs. This article seeks to contribute to this general debate by focusing on one of the purported benefits of such commissions that may be somewhat under-appreciated. This is the creation of public awareness, during the life of the commission itself, about the nature and extent of the particular grave threat that confronts the society in question. It is contended that, mediated by a free and vibrant press, the public narrative that emerges during the operation of a commission of inquiry may serve to make a liberal democratic society more resilient in the face of threats to that society's continued existence. This article seeks to support this contention by focusing on an important precursor to the more recent commissions of inquiry on corruption in South Africa - that is, the Jali Commission of Inquiry into corruption within the South African penal system, which sat in the early years of the new millennium. By analysing the many articles and reports that appeared in a range of South African newspapers during the initial hearings of the Jali Commission, this article documents the emergence of an important public narrative on corruption within South Africa's prisons, and reflects upon the ultimate significance of this narrative. This article is divided into two parts: the first part deals with the initial hearings of the Jali Commission in KwaZulu-Natal, and the second part with subsequent hearings in the Free State.

\section{INTRODUCTION}

At the time of writing this article - just over a quarter of a century since the collapse of the apartheid system - South Africa finds itself in a difficult position. With the economy of the country devastated by the effects of 
rampant criminality within both the public and private sectors, South Africa appears to have run out of easy political and economic options. ${ }^{1}$ There is open acknowledgement (even from powerful politicians within the ruling party) that "state capture" has played a major role in weakening the country. ${ }^{2}$ Furthermore, the realisation that many years of rampant corruption have caused incalculable damage to South Africa's economy and polity extends to the South African public at large. ${ }^{3}$ Without necessarily seeing eye to eye on all the details, South Africans as a whole seem to agree on both the general cause and extent of the problem. Clearly, acknowledgement of a problem is a necessary first step towards its eventual resolution.

The focus of this article is on a tool that various governments in South Africa, both pre- and post-apartheid, have adopted when confronted with public crises of significant magnitude - that is, the appointment of a highlevel public commission of inquiry. The present series of crises faced by the country - all involving the general issue of corruption - have resulted in the appointment of a series of commissions of inquiry into various manifestations of the problem. Within nine months of replacing Jacob Zuma

1 According to the journalist, author and anti-apartheid activist Jacques Pauw: "Our state institutions have been hijacked for the benefit of the elite few. The public protector's State of Capture report and the thousands of leaked Gupta e-mails have painted a sordid picture of the extent to which the state, the government, the ANC and the president have been infiltrated and turned into enablers of the violation of our sovereignty. This has impoverished the nation, crippled key state institutions and jeopardised our security." Pauw The President's Keepers: Those Keeping Zuma in Power and Out of Prison (Kindle ed.) (2017) ch 17 par 2.

2 On 25 January 2018, the then-Deputy President of South Africa, Cyril Ramaphosa, told Zeinab Badawi, who was interviewing him for the British Broadcasting Corporation's (BBC) Hardtalk programme: "Everyone agrees that our state was captured by corrupt elements, by people who purported to be close to the president, who have been doing really bad things getting into many state institutions" (BBC News (25 January 2018) http://www.bbc.com/news/av/world-africa-42821474/ramaphosa-south-africa-captured-bycorrupt-elements). Another example of open acknowledgement by a top politician of the reality of "state capture", together with the expression a considerable degree of angst, is to be found in the words of Ronnie Kasrils, a member of the National Executive Committee of the African National Congress from 1987 to 2007 and Minister for Intelligence Services in the South African government between 2004 and 2008: "Where and how did the rot all start? And who can we say was responsible? Do we blame individuals, the liberation movement, South African society, capitalism, the world we live in, human nature, an unfathomable enigma? Is there something innate about the human condition which makes people susceptible to greed, the lust for wealth and power? Can such flaws be overcome, can temptation be resisted or at least contained by mere appeals to conscience, by whistleblowing, by tough regulations and penalties?" Kasrils A Simple Man: Kasrils and the Zuma Enigma (Kindle ed.) (2017) ch 32 par 1.

3 The intense emotions that characterise public debates on the issue of corruption in South Africa is apparent in the following quotation from a recently published book on the topic of corruption at the highest levels of the South African state by journalists Adriaan Basson and Pieter du Toit: "Through his misrule, Zuma and his circle of rogue protectors broke not only the country's spirit and moral fibre, but also our hearts. By allowing his son and dodgy friends to run amok and operate what is effectively a parallel state, by appointing compromised individuals to protect him and his cronies from prosecution, by weakening the state's investigative capacities to the point of institutional collapse, and by allowing weak and incompetent sycophants to manage key service-delivery departments, Zuma broke his oath of office and became an enemy of the people he had promised to serve" (Basson and Du Toit Enemy of the People: How Jacob Zuma Stole South Africa and How the People Fought Back (2017) 107-112). 
as president of South Africa in February 2018, Cyril Ramaphosa appointed no fewer than four commissions of inquiry: the Zondo Commission (also known as the State Capture Inquiry) into allegations of state capture; the Nugent Commission (also known as the SARS Commission) into tax administration and governance by the South African Revenue Service; the Mpati Commission (also known as the PIC Inquiry) into allegations of impropriety regarding the Public Investment Corporation; and the Mokgoro Enquiry (also known as the NPA Enquiry) into the fitness of the deputy national director of public prosecutions, Nomgcobo Jiba, and the special director of public prosecutions, Lawrence Mrwebi, to hold office. ${ }^{4}$ With the appointment of so many commissions of inquiry within such a short period of time, questions have arisen as to whether such inquiries are worth the considerable costs involved in their operation. ${ }^{5}$

Following a brief overview of certain of the traditional arguments advanced both for and against the appointment of commissions of inquiry in times of public crisis, this article focuses on one particular objective that is said to form part of the aims of a commission of inquiry appointed in such circumstances - that is, the objective of educating the public on the nature and scope of the crisis in question, including the attribution of responsibility for what went wrong. This article does not focus on the educative and/or archival role of the final report produced by each such commission of inquiry, the production of which is clearly a formal objective of each such inquiry. Rather, this article seeks to shed light on the process that happens during the life of such commissions - at least within a constitutional democracy, with a vibrant free press, when the process works well.

This article contends that the true impact of a public commission of inquiry within a constitutional democracy such as South Africa is not restricted to the "official" impact of its final report on government functionaries. Much of the impact of such a commission of inquiry depends upon the narrative that is constructed in and mediated via the public media (in particular, the free press) during the life of a commission. So stated, this point may seem somewhat obvious. However, it is the contention of this article that the creation of public awareness over an extended period of time, about the nature and scope of a serious social problem (such as the existence of large-scale corruption within a range of important social institutions), is a significant but under-appreciated benefit of the appointment of a public

4 What became known as the State Capture Inquiry (or Zondo Commission) was constituted on 8 February 2018, with Deputy Chief Justice Raymond Zondo as Commissioner; the SARS Commission (or Nugent Commission) was constituted on 24 May 2018 with retired Justice Robert Nugent as Commissioner; the PIC Inquiry (or Mpati Commission) was constituted on 17 October 2018, with former Supreme Court of Appeal President Justice Lex Mpati as Commissioner; the NPA Enquiry was constituted on 9 November 2018, with former Justice of the Constitutional Court Yvonne Mokgoro as Chairperson of a threemember Panel.

5 See, for e.g., Powell "South Africa's Commissions of Inquiry: What Good Can They Do?" The Conversation (8 November 2018) https://theconversation.com/south-africascommissions-of-inquiry-what-good-can-they-do-106558 (accessed 2020-11-25); see also Mohale "Three Reasons Why SA Needed the Commissions of Inquiry" SABCNewsOnline (24 January 2019) https://www.sabcnews.com/sabcnews/three-reasons-why-sa-neededthe-commissions-of-inquiry/ (accessed 2020-11-25). 
commission of inquiry in times of crisis. ${ }^{6}$ Of course, a vibrant free press will report upon the existence of social ills and create public awareness, even in the absence of a commission of inquiry. This article argues, however, that the appointment of a public commission of inquiry provides an official "stamp of approval" to the often-difficult process of dragging a particularly intractable and serious social problem into the public spotlight. It is contended that, in the best cases, media reporting around the often long drawn-out proceedings of a public commission of inquiry serves to keep serious threats to constitutional democracy constantly in the public mind; it is an intangible but important bulwark against those forces that seek to undermine the principles of such a constitutional democracy.

This article seeks to illustrate the point by an in-depth analysis of the media reporting surrounding an important precursor to the various commissions of inquiry appointed in 2018 that are mentioned above. The commission in question is the Jali Commission of Inquiry into corruption within the South African penal system, which sat between 2001 and 2005. By examining a large number of reports that appeared in a range of national newspapers during the first months of operation of the Jali Commission, this article seeks to achieve two main objectives: first, to set out the narrative in all its urgency and immediacy, as it was actually conveyed to the South African public over many weeks, through factual reporting and editorial commentary; secondly, to comment on the possible significance of this narrative, and its implication for the wider question of whether such expensive public commissions of inquiry (including commissions that are at present ongoing) are ultimately justified in a country such as South Africa.

In setting out the narrative in accordance with the first objective, this article seeks to capture what may be referred to as a "living history" (the basic details of which were later confirmed in the official report of the Jali Commission (Jali Commission Report) $)^{7}$ of the often banal manner in which corruption was able to take hold and thrive within an important part of the

6 Public awareness, created by free and ready access to relevant information through the media, is clearly crucial to the continued health of a constitutional democracy. This point was made forcefully by South African Constitutional Court Justice Sandile Ngcobo in an address to the Constitutional Conference that took place in 2010 on the topic "Freedom of Information and Freedom of Expression: The Bedrock of Democracy". Justice Ngcobo's views on this important point were summed up as follows: "In the keynote address, Justice Ngcobo spoke about the constitutional rights to freedom of expression and access to justice, and the role of the media in a democratic society ... He said that access to information was the 'oxygen of democracy' and, together with an independent press, was the foundation of democracy ... Justice Ngcobo said that access to information led to transparency in government, which was essential for democracy, and could combat corruption - the biggest threat to democracy. He said that secrecy provided a 'fertile ground for corruption' and that, in terms of the Declaration of Principles on Freedom of Expression in Africa, disclosure of information should be the rule and non-disclosure the exception" (Manyathi "Access to Information is the Oxygen of Democracy: Justice Ngcobo" 2012 De Rebus 12).

7 Jali, Steyn, Sishi and Poswa-Lerotholi Commission of Inquiry Into Alleged Incidents of Corruption, Maladministration, Violence or Intimidation Into the Department of Correctional Services Appointed by Order of the President of the Republic of South Africa in Terms of Proclamation No. 135 of 2001, as Amended: Final Report (December 2005) https://www.gov.za/sites/default/files/gcis_document/201409/jalicommfull0.pdf. 
South African state apparatus - namely, the Department of Correctional Services - during the post-liberation period. It also seeks to capture the immediate public reactions of South Africans to the "drama of corruption" that was being played out before them. In commenting on the narrative in accordance with the second objective, this article seeks to gauge the effects upon the South African public psyche - in particular, whether such effects may in some way have better prepared South Africans for present and future battles against the scourge of corruption.

It is clear that, in order to achieve its objectives, this article needs to cover much ground. The hearings of the Jali Commission took place over a number of years across the length and breadth of South Africa, with hundreds of newspaper articles being written about the hearings. It is thus impossible - in a relatively short article such as this - to cover in a nuanced way the public discourse surrounding all the hearings of the commission. Therefore, this article restricts itself to a close analysis of the debates surrounding the first two sets of hearings: those held in KwaZulu-Natal, and those in the Free State. In accordance with this focus, the article is divided into two parts: the first part deals with the initial hearings of the commission in KwaZulu-Natal; and the second part deals with the hearings in the Free State. Although not all hearings of the commission are dealt with, it is submitted that the picture of corruption that emerges within the public narratives surrounding this issue is sufficiently detailed and nuanced so as to allow valid conclusions to be drawn.

\section{COMMISSIONS OF INQUIRY: ARGUMENTS FOR AND AGAINST}

Scholars commenting on the value of judicial commissions of inquiry often mention that such commissions can be an important government instrument. Usually, of course, this instrument is reserved for dealing with matters of great public importance, such as a nationwide crisis of confidence. For example, commenting on the value of appointing commissions of inquiry in South Africa - albeit during the apartheid period - Professor AJ Middleton points out that the practice is "sometimes regarded with a certain degree of scepticism", but notes the value of such commissions as "an important tool of government". ${ }^{8}$ Another example of this traditional argument that commissions of inquiry are an important part of the government's "toolbox" is advanced by Canadian Justice John H. Gomery, who states as follows:

8 Middleton "Notes on the Nature and Conduct of Commissions of Inquiry: South Africa" 1986 XIX Comparative International Law Journal of Southern Africa (CILSA) 252252 and 256. Professor Middleton cites an article in the New Zealand Law Journal listing the following benefits of a commission of inquiry: "(i) It is an important tool of government; (ii) it provides the means of arriving at a balance between public and private good; (iii) it assists the government to formulate policy; (iv) it enables an examination of conflicting expert opinion; (v) it tests the strength of opposition to a project; (vi) by giving more individuals and groups an opportunity to express their views, public inquiries provide public authorities with a more precise appreciation of the public's requirements and expectations; and (vii) from the citizen's point of view, commissions of inquiry provide an opportunity to participate in the process of decision-making which affects their lives" (Black "Commissions of Inquiry" 1980 19 New Zealand Law Journal (NZLJ) 427, quoted in Middleton 1986 XIX CILSA 256). 
"Public inquiries are a regular part of the political landscape in Canada. There have been over four hundred of them since Confederation in 1867, if you include provincial commissions of inquiry ... They constitute what has been described by the Supreme Court of Canada as 'a significant and useful part' of our democratic traditions, both in Canada and elsewhere." ${ }^{\prime}$

This generally positive view of commissions of inquiry as being useful "democratic tools" that may assist a government with its duties (such as adopting rational policies in response to problems) is not, however, adopted by all scholars in this field. Adam Ashforth, for example, argues that commissions of inquiry are a special kind of institution within the modern state, standing apart from the main institutions of political power and deploying "forensic procedures" in their investigations. As opposed to being simple "policy-making instruments", Ashforth regards their work as "reckoning schemes of legitimation" that "serve in constituting a realm of discourse through which collective action vis-à-vis Society by those who act in the name of the State becomes thinkable, and thereby organizable". ${ }^{10}$ Ashforth's more critical stance on the role of commissions of inquiry within capitalist liberal democracies is well expressed in the following quotation:

"[T]he hearing of oral evidence continues as a central time- and moneyconsuming pastime of public inquiries. The main reason for this lies in the veracity lent to inquiry by public hearings. Public 'sittings' by Commissions of Inquiry can be considered as a form of symbolic ritual, akin to the holding of Court but in a modern rationalized form, wherein the subjects of State power speak, and are heard. As such, they have rather less to do with the 'gathering of facts' than with expressing the truth of power. That 'truth' being that State power serves the interest of all citizens and is open to their views. On the symbolic level, then, by appointing a Commission of Inquiry a Government pays homage to this truth and serves notice of its desire to serve the common interest in the most rational way."11

Having noted the above critique (which operates at a somewhat abstract ideological level), it is useful to touch briefly on certain of the more prosaic arguments frequently raised in opposition to the use of commissions of inquiry in capitalist liberal democracies. One such argument is that commissions of inquiry may operate as a means for corrupt or incompetent politicians who are under immediate pressure from the public to account for a crisis caused by their misdeeds or incompetence to temporarily shift the focus away from themselves, in the hope that the delay caused by the investigative process will result in the public forgetting about whatever issue gave rise to the public anger in the first place. The regularity with which this argument is put forward is clearly expressed in the following quotation:

"[l]f Commission reports appear to be frequently ignored by the governments which commission them, they are ignored in the vast majority of instances by the general public. Another well-known and cynical suggestion is that Commissions of Inquiry serve no other purpose than obfuscation and delay."12

9 Gomery "The Pros and Cons of Commissions of Inquiry" 200651 McGill Law Journal 786-787.

10 Ashforth "Reckoning Schemes of Legitimation: On Commissions of Inquiry as Power/Knowledge Forms" 1990 3(1) Journals of Historical Sociology (JHS) 1.

11 Ashforth 1990 JHS 12.

12 Ashforth $1990 \mathrm{JHS} 2$. 
Another frequent argument against the appointment of commissions of inquiry is that they may cost far more than they are worth. This common concern is clearly articulated in the following extract from an opinion piece on the cost of recent commissions into various forms of corruption in South Africa:

"These commissions are not coming cheap at all. For example, the Inquiry into State Capture will cost no less than R230 million in the first six months and it is expected to run for two years or more ... From this, one can conclusively deduce that taxpayers will part with close to a billion rand to sustain these commissions. The irony of it all is that to uncover the truth is coming at a huge price. But that is also the sad truth about corruption: it is costly."13

Clearly, the various sceptical arguments mentioned above are valid to a certain degree. The purpose of this article, however, is to focus on one of the more beneficial aspects of public commissions of inquiry in a constitutional democracy such as South Africa. As pointed out in the introduction to this article, this involves the important role that such commissions play in informing and educating the public about particularly serious threats to constitutional democracy itself. This article contends that, having been in some sense "inoculated", an educated and informed public is better able to mount an effective defence against those who would subvert the basic rights and freedoms characteristic of liberal constitutional democracies. As was pointed out in the introduction to this article, however, not all aspects of the "educational function" of such commissions are examined here. In order to appreciate the particular point of focus of this article concerning the educative function of such commissions, it is useful to make reference to a set of distinctions made by Adam Ashforth in this regard. Ashforth maintains that the "discursive work" of commissions of inquiry takes place in three phases. The first phase is "investigative" and takes place "during the life of the particular Commission when the Commissioners, official representatives of the State chosen by the Government from the ranks of Civil Society, are engaged in discussion with representatives of social interests". ${ }^{14}$ The second phase, which Ashforth calls the "persuasive phase", begins after the publication of the commission report, which Ashforth characterises as an "invitation to discussion", symbolising "a sort of dialogue between the State on the one hand and Society on the other". 15 The third phase is the "archival" phase, during which "reports enter a dialogue with history" and "become a

13 Mohale https://www.sabcnews.com/sabcnews/three-reasons-why-sa-needed-thecommissions-ofinquiry/ (accessed 2020-11-25).

14 Ashforth 1990 JHS 6.

15 Ashforth 1990 JHS 6. The public dialogue referred to by Ashforth around the reports of commissions and committees of inquiry is nicely described in the following words of Gerald Rhodes: "The reports of committees are public documents. They often contain a wealth of information in addition to discussion and specific recommendations for action. They are commented on by newspapers, by professional and technical journals, sometimes by academic commentators. The question is, therefore, what the significance of such reports is, not simply in terms of the reactions of civil servants and ministers poring over them in their offices, but in this wider public context" (Rhodes Committees of Inquiry (1975) 149). 
source of historical 'facts"'.16 The focus of this article is on the "discursive work" that takes place during the investigative phase referred to above - that is, during the life of the commission of inquiry.

As pointed out in the introduction, a central task of this article is to examine closely the many articles and reports that appeared in a range of South African newspapers during the first part of the life of the important Jali Commission of Inquiry into the South African penal system, just after the turn of the millennium. ${ }^{17}$ It is contended that, coupled with a free and vibrant press, the evidence given before a public commission of inquiry can be a powerful instrument to protect a liberal constitutional democracy against the ravages of corruption and other forms of malfeasance perpetrated by the powerful. Of course, this applies not just to South Africa, but to constitutional democracies generally, as is illustrated in the following comment of Canadian Justice John H. Gomery:

"[A]ll of these powerful people were obliged to answer questions about their actions and involvement in a controversial government program whether they wanted to or not. They were expected to explain their actions, and to account for the manner in which they had discharged their public responsibilities, to an independent body carrying out its investigation in public, in the full glare of television coverage." 18

Returning to the specific application of this point in the South African context, it is submitted that (when confronting the worst abuses of power, such as occurred in South Africa during the apartheid period, or the systemic corruption that has undermined entire institutions of state during the postapartheid period), the "public narrative" that accompanies a major public commission of inquiry is an essential part of what makes such commissions effective in defending democracy and the rule of law. It is not simply the narrative contained in the eventual report of a particular commission of inquiry that serves effectively to counter the corrosive effects of corruption and abuse of power, but also the public narrative that accompanies hearings of the commission and which is reflected in the public media. In commenting on the potential value of two prominent South African commissions of inquiry set up in recent years in the aftermath of the controversial Zuma presidency to investigate various forms of irregularity and corruption, Cathleen Powell makes this point cogently:

Ashforth 1990 JHS 6.

7 At this point, it is worth noting the old adage: "News is a first rough-draft of history." This phrase first appeared in the 13 June 1948 edition of the Washington Post (Washington Post (13 June 1948) https://slate.com/news-and-politics/2010/08/on-the-trail-of-thequestion-whofirst-said-or-wrote-that-journalism-is-the-first-rough-draft-of-history.html (accessed 2020-1125).

18 Gomery 2006 McGill LJ 787. Gomery was commenting on the Canadian "Sponsorship Inquiry", which took place in 2006. Of course, not all aspects of the publicity resulting from public evidence given to a high-profile commission of inquiry is necessarily positive and supportive of justice in a liberal constitutional democracy. In counterpoint to his generally favourable opinion of the role of commissions of inquiry in Canada, Justice Gomery quotes Edward Greenspan QC, a Canadian defence lawyer: "Commissions of inquiry are bound by no rules of evidence. Anything goes. At public inquiries, witnesses are able to tarnish the reputation of others before a nationwide television audience. Trials, because of their solemnity, are not televised in Canada. And rightly so" (Gomery 2006 McGill LJ 788). 
"[C]ommissions of inquiry don't remove an issue from the public eye if they're run openly and transparently. Instead, they draw the public in to the issue, educating and inviting engagement. The most important work of the Zondo and Nugent Commissions might be done before their formal function - the submission of their reports - is completed." 19

Powell points out that, in performing their educational function, commissions of inquiry may serve to ensure public "buy-in for important processes of change and renewal." ${ }^{20}$ It is submitted that Powell's point is particularly crucial when taking into account the sheer scale and extent of the social, political and economic problems faced by South Africa as a result of decades of corruption. Calling on ordinary South Africans to make significant personal sacrifices - to put right the damage caused by the corrupt activities of others over many years - is clearly not possible without significant public "buy-in", as Powell terms it. It is argued in this article that a properly and expertly conducted commission of inquiry, working in tandem with a responsible free press, is able to operate as a powerful tool to achieve this crucial public "buy-in".

\section{PUBLIC DISCOURSE SURROUNDING THE HEARINGS OF THE JALI COMMISSION IN KWAZULU-NATAL}

The subheadings below trace the public narrative as reflected in the many newspaper articles and reports that emerged around the initial hearings of the Jali Commission of Inquiry, which were held in KwaZulu-Natal. The public shock and anger that greeted the revelations are apparent in the narrative that emerged.

\section{The establishment of the Commission}

The immediate event that gave rise to the establishment of the Jali Commission of Inquiry into alleged incidents of corruption, maladministration, violence and intimidation within the South African penal system was a brutal murder that took place on 26 June 2001. The victim was a certain Ms Thuthukile Bhengu, who had been in charge of Human Resource Management in the KwaZulu-Natal Provincial Office of the

19 Powell https://theconversation.com/south-africas-commissions-of-inquiry-what-good-canthey-do-106558 (accessed 2020-11-25). Powell's rejection of the common misconception that the appointment of a commission of inquiry automatically leads to a reduction in public concern about the issue being investigated receives solid support from Raanan SulitzeanuKenan. Sulitzeanu-Kenan refutes the "common claim" that "the appointment of an inquiry acts to reduce the level of public interest in the affair [which led to such appointment]", stating that "despite the prevalence of this claim, no empirical support was found for any mitigating effect of inquiry appointment on media salience in recent studies" (SulitzeanuKenan "Reflection in the Shadow of Blame: When Do Politicians Appoint Commissions of Inquiry?" 2010 40(3) British Journal of Political Science (BJPS) 617).

20 Powell https://theconversation.com/south-africas-commissions-of-inquiry-what-good-canthey-do-106558 (accessed 2020-11-25). 
Department of Correctional Services. She was gunned down in the study of her home near Pietermaritzburg's Napierville Prison. ${ }^{21}$

Although it was generally known that violence and intimidation existed within the Department of Correctional Services, the murder of Thuthukile Bhengu was particularly shocking to members of the Department, because, in the words of the final report of the Jali Commission of Inquiry published four and a half years later, "even though ... sinister forces operating in the Department had been violent towards male and female members previously, at no stage had a female member been murdered". ${ }^{22}$ The Commission commented further that, "[i]n the eyes of the ordinary law abiding members" of the Department, the murder of Thuthukile Bhengu "gave the impression that the sinister forces within the Department were prepared to go to any extent to achieve their objectives". ${ }^{23}$ The Commission noted that, during this period, intimidation and fear were prevalent within the Department, including its Head Office. ${ }^{24}$

Following Thuthukile Bhengu's murder, the Minister of Correctional Services, Ben Skhosana, decided to call for a national inquiry. In August 2001, Durban High Court Judge Thabani Jali was appointed to head a national commission of inquiry to investigate and report on incidents of corruption, maladministration, violence or intimidation within the Department of Correctional Services. ${ }^{25}$

On 1 February 2002, it was reported that eight prisons throughout the country were to be investigated by the Commission, with the DurbanWestville and Pietermaritzburg Prisons being at the centre of the inquiries. ${ }^{26}$ On 4 February 2002, the Commission started hearings in the Durban magistrates' court that were due to last for five weeks. ${ }^{27}$ Advocate Vas Soni, who was leading evidence for the Commission, stated that three prisons in KwaZulu-Natal were part of the initial enquiry. They were the DurbanWestville Prison, the Ncome Prison in northern KwaZulu-Natal, and the Pietermaritzburg Prison. It was at the Ncome Prison that senior correctional officer Sipho Khumalo had been shot dead by a colleague in 1999, and at the Pietermaritzburg Prison that Thuthukile Bhengu had been murdered in 2001. It was also reported that Bhengu's killers were expected to appear in court in June 2002. ${ }^{28}$

21 Two senior correctional officers, Mr Mlungisi Dlamini and Mr Lucky Mpungose, were charged with her murder. They were found guilty in June 2002, and were sentenced to life imprisonment. The evidence before court was that Ms Bhengu had refused to consider a fraudulent job application from Mr Mpungose's fiancée (Jali Commission Report Vol 127 fn 43).

22 Jali Commission Report Vol 126.

23 Ibid.

24 Ibid.

25 (2001-08-24) Natal Witness 2. The Jali Commission of Inquiry was appointed in terms of Proclamation Number 135 of 2001, published in GG 22718 of 2001-09-27. See Jali Commission Report Vol 15.

26 (2002-02-01) Pretoria News 3.

27 (2002-02-01) Daily News 2.

28 (2002-02-05) Star 5. 


\section{Shocking allegations of rampant corruption in the prisons of KwaZulu-Natal}

Press reports conveyed the seriousness of the situation confronting South Africa's penal system at this time. For example, in addressing Mr Justice Thabani Jali at the start of the Commission on 4 February 2002, Advocate Vasi Soni was reported to have stated that the prison system needed a complete overhaul - so that the climate of fear, which allowed lawless behaviour to prevail within the system, could be eradicated. Referring to prison officials who saw themselves as "untouchable and above the law", he stated that it was the task of the Commission "not only to touch (the untouchables) but also to bring them down", and added that the Commission was "the last chance saloon" for the Department of Correctional Services". ${ }^{29}$ He referred to two specific instances of corruption. In one instance, an official allegedly extorted money from a former prisoner. The Department of Correctional Services was supplied with proof in the form of bank slips that payments had been made into the official's bank account, but the only action taken against him was that he was transferred. In another instance, it was alleged that five officials had submitted fraudulent qualifications. While the cases against three of the officials were still pending, the other two had simply received a written warning. According to Soni:

"This is an invitation to other officials that they can do what they want without any action being taken." 30

The KwaZulu-Natal Commissioner of Correctional Services, Mr Patrick Gillingham, was cross-examined by Advocate Soni. He asked a number of questions based on allegations of corruption within the Durban-Westville Prison and which had been published in the press. Among these questions were the following: how a convicted drug dealer had received parole without serving a day in prison; how a tycoon had served a two-year sentence while living in a palatial home and in various five-star hotels; why the prison employed people with criminal records; how a prisoner received a job as a warder at Westville Prison; and how the chairman of the parole board could say that child abuse was not a serious crime. Furthermore, with regard to a man who was referred to in the press as "Westville's Mr Untouchable", Soni asked the following:

"Who is this man who is untouchable at Westville Prison who is so highly placed that nobody can do anything to him? What action has been taken against him for what can only be described as criminal acts? Has he been arrested? Is he suspended?"31

The Commissioner said that he would reply to these questions at a later stage. ${ }^{32}$

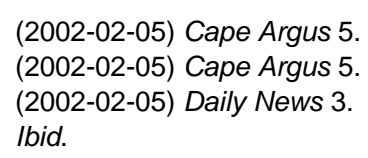


On 5 February 2002, the manager of the elite Emergency Support Team (EST) at the Westville Prison, Hendrik van Heerden, gave evidence before the Jali Commission, which made for sensational reading in the press. $\mathrm{He}$ told the Commission he was certain that prisoners were being taken out of the prison in the boots of cars in order to commit crimes:

"It's the perfect crime. The prisoner will never be convicted unless he is caught in the act because he is officially in prison when the crime takes place. They are usually back in time for the afternoon count. If you wanted a particular type of criminal for a particular crime, you could easily find that person in prison." 33

Van Heerden also alleged that vehicles were admitted to the prison without searches; that guards sold and rented their departmental residences to persons not employed by the Department of Correctional Services; and that guards ran shebeens from their quarters. He claimed that a high level of fear and intimidation existed within the Department of Correctional Services, and he told the Commission that his office had been ransacked when it became known that he was due to testify at the Commission. He stated further:

"I know guards who have information but are afraid for their lives. This commission will fail unless intimidation is addressed and people come forward. It is unfortunate that you can't protect everyone all the time and 'accidents' will happen." 34

Van Heerden claimed that a particularly high level of intimidation and fear pervaded the Pietermaritzburg New Prison:

"[People there] shoot first and ask questions later. There is a sense of people getting away with things in Pietermaritzburg. Intimidation is so high even the EST is scared of doing its job." 35

Van Heerden also informed the Commission that he suspected corruption among investigating officers at the prison. He told the Commission of an incident in which the Emergency Security Team had confiscated a batch of mandrax tablets from prisoners, and had then marked them before handing them to a prison officer for investigation. The marked batch of tablets found its way back into the hands of prisoners, and was again confiscated by the EST during a subsequent raid. Van Heerden told the Commission that the main drug couriers in the prison appeared to be warders who were employed by drug syndicates that operated both inside and outside the prison. Several guards who had been caught with drugs had not been dismissed. The main route for smuggling drugs into the prison appeared to be through the kitchen. ${ }^{36}$

On the same day that Van Heerden gave his evidence, Michael Johannes Buitendag, a prison warder at Westville Prison, also appeared before the Commission. He stated that he had addressed 36 written complaints to the Department of Correctional Services to repair damaged scanners, X-ray

\footnotetext{
(2002-02-06) Natal Witness 1.

(2002-02-06) Natal Witness 1.

Ibid.

Ibid.
} 
machines and metal detectors, but without success. He stated that he had written the report so many times that he could "write it blind-folded". ${ }^{37}$ The equipment was necessary to check prisoners for illicit drugs and weapons. He stated that most drugs entered the Westville Prison through the kitchen. Another witness, Bongani Shadrack Gumede, who was an investigator in the Youth Centre, told the Commission that drugs were a major problem in the prison and that he believed that about 90 members of the prison staff were involved. ${ }^{38}$

The following day, the commission heard evidence surrounding the remark by the head of the parole board at Westville Prison, Bongani Magubane, that child abuse was not a serious crime like murder or rape. The remark had been made in court in support of a convicted childmolester's parole application. The prosecutor who had opposed the parole application, Vanshree Moodley, told the commission that she had found Magubane's statement "incredible and disgusting". ${ }^{39}$ The commission recommended that Magubane be relieved of his duties as chairman of the parole board. ${ }^{40}$

On 7 February 2002, the Natal Witness commented on the testimony given before the commission, inter alia, as follows: "Some alarming testimony is presently being given to the commission, and
those who do so are also to be commended because of the risk they take of
possible retribution ... It seems that civilised prison norms have yet to be
achieved in this country." 1 .

The next day, the commission was in the news once again. It was reported that the provincial correctional officer for functional services, Innocent Zulu, told the commission that Pietermaritzburg's New Prison was the most problematic prison in KwaZulu-Natal. The high number of escapes from the prison indicated that there was "definitely something wrong", and that the prison appeared to have a unique culture of intimidation. During the hearing, reference was made to a senior departmental investigator from the Department of Correctional Services Anti-Corruption Unit who was forced to leave KwaZulu-Natal because his life was threatened. Zulu admitted that there were many people in the Department of Correctional Services with relatives also working in the department, but he denied that he was instrumental in securing a job for his wife in the department during 1998.42

A few days later, Police and Prison Civil Rights Union shop steward, Fanu Makhathini, told the commission that corruption, nepotism and favouritism were so rife at Westville Prison that warders were ashamed to wear their

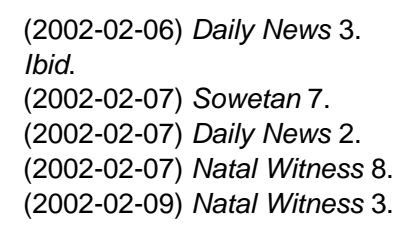


uniforms in public. Warders in uniform were pestered by members of the public, who offered them bribes in return for jobs or tenders. ${ }^{43}$

On 11 February 2002, further dramatic details concerning evidence presented to the commission appeared in the press. It was reported that Claude King, a prisoner confined in Westville Prison, had asked the commission for police protection before testifying against corrupt warders. $\mathrm{He}$ told the commission that several threats had been made against him since it became known that he was cooperating with the commission. Prisoner Gregory Christensen told the commission that he had paid two warders to take him home on a number of occasions to visit his wife. One warder had charged him R500 per visit and the other had charged him R100 per visit. Once this became too expensive for Christensen, one of the guards offered him money in return for Christensen's assistance in selling drugs inside the prison. The guard supplied R500 worth of cannabis for Christensen to sell every week. Christensen later began dealing in mandrax on behalf of the guards. He bought mandrax tablets for R20 each from the guards and sold them to other drug dealers inside the prison for R25 each, and directly to drug users for R30 each. He sold up to 50 tablets per week. Eventually he acquired a cellphone that he would use to purchase drugs from dealers outside the prison. Guards would pick up the drugs and transport them to the prison in return for R500. Many guards were involved in the scheme. Christensen eventually reported his activities, and those of the corrupt guards, to a senior warder, but by the time he returned to his section, two of the corrupt guards already knew that he had discussed their illegal activities. He told the commission that he had no confidence in the system. ${ }^{44}$ Advocate Vas Soni later commented on Christensen's attempt to extricate himself from the drug syndicate:

"The whole prison system crumbled and crushed a vulnerable man who wanted to get out of a vicious circle of drug dealing." 45

Press coverage of the dramatic evidence presented to the commission continued the next day when it was reported that Judge Jali had agreed to afford Claude King protection by having him removed from KwaZulu-Natal. King gave evidence in support of the evidence given by Gregory Christensen. He stated that he was present when a warder, Mr Karl Viljoen, gave Christensen mandrax tablets. He also told the commission that warders Devan Maharaj, Devan Brijlall and Leon Pakiri had given mandrax to Christensen. Christensen's wife Joanne also supported Christensen's testimony. She told the commission that guards had brought her husband home on about 20 separate occasions for illegal visits. She was able to describe the car driven by one of the guards and told the commission that her son was conceived during one of the illegal visits. ${ }^{46}$

On 13 February 2002, a prisoner sentenced to life for the murder of two young boys and confined in the Westville Prison, Kistensamy Govender, told

\footnotetext{
(2002-02-11) Sowetan 4.

(2002-02-12) Natal Witness 1. See also (2002-02-12) Sowetan 4.

45 (2002-02-15) Sowetan 7.

46 (2002-02-13) Natal Witness 2. (2002-02-13) Daily News 1.
} 
the commission that the kitchen area of the prison was the "nerve-centre for smuggling". Prisoners and warders came together in this area for food. Prisoners sent to wash the warders' cars retrieved drugs and alcohol, wrapped in black plastic bin bags, from the vehicles. These bags were then stored in the kitchen storeroom. Govender alleged that on one occasion he had opened a bucket of peanut butter in the kitchen storeroom and found that it was full of cannabis. He testified further that he had once seen a warder, Nhlanhla Radebe, giving a prisoner three plastic bags of cannabis, which were later found in that prisoner's cell. This incident was never investigated. Govender stated that he sold surplus bread to the prisoners, and that for every R100 he made, he gave R80 to Andre Ntombela who ran the kitchen. ${ }^{47} \mathrm{X}$-rated movies, alcohol and drugs were readily available over the counter at the prison kitchen. A nip of spirits cost R20 and a full bottle cost R100. He told the Commission that he watched X-rated movies at least twice a week. ${ }^{48}$ Govender was also reported to have told the Commission:

"When I was transferred to Medium C, it was like walking into a casino. Warders and prisoners gambled together. Alcohol, drugs and sex were freely available. I became part of that." 49

Advocate Vas Soni later praised the prisoners who had testified and called for President Thabo Mbeki to appoint a "crack task team" to investigate charges against the warders who had been implicated in drug dealing. $\mathrm{He}$ stated that it would be a complete waste of taxpayers' money to leave the criminal investigation to the Westville Prison prison authorities who had proved themselves to be hopelessly inefficient. ${ }^{50}$ Advocate Soni also called for the dismissal or transfer of the deputy head of Westville Prison, Maduramuthoo Sigamoney - accusing him of ignoring the unlawful conduct of warders and inmates and turning a blind eye to the illegal activities within the prison. ${ }^{51}$

On 15 February 2002, the Sowetan commented inter alia in an editorial:

"The shocking testimonies of prisoners, particularly about syndicates operating in cahoots with warders in the prison, are consistent with claims made by other inmates at other institutions in the past. Such evidence is not entirely unexpected but instead confirms long-standing suspicions that some of the country's prisons have become dens of corruption in the iron grip of a coterie of powerful warders. Many of the prisoners have been known to act as middlemen in the chain of corrupt activities to protect their principles, who invariably are warders. Essentially, as evidence before the commission has underlined, prisoners have become nothing more than a captive market for corrupt warders who peddle anything from drugs to blue movies with impunity." 52

Extensive press coverage of the evidence presented to the commission continued in the days that followed. On 18 February 2002, Westville Prison

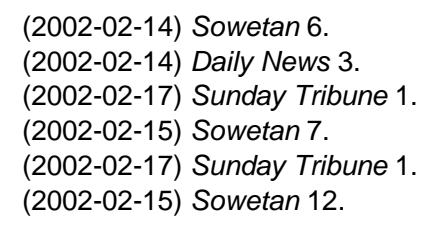


area manager Terence Moses Sibiya gave evidence. He stated that the prison had the highest number of staff assaults on prisoners in KwaZuluNatal. He told the commission about one incident, which involved six warders who had assaulted a prisoner by the name of Elvis Ngcobo. The prisoner died and the warders were found guilty of "causing the death" at a disciplinary hearing. Aside from a verbal warning, no other action was taken against the warders. According to Sibiya:

"The outcome was not a reasonable outcome but policy does not allow us to take the matter further." 53

Judge Jali challenged Sibiya, and asked him whether he needed policy documents to tell him that a murder investigation should be opened in this case. He stated that the matter should have been raised with the provincial or national correctional services commissioner. ${ }^{54}$

Another incident involved a finding by an internal prison tribunal, to the effect that an official had allowed a certain prisoner to spend "more nights out of prison than inside". The prisoner concerned was a certain Chicago Mtshali, who, according to the Sowetan, had "made newspaper headlines recently for his escapades outside prison while still a prisoner". ${ }^{55}$ The official concerned was let off with a mere warning, and although Sibiya was dissatisfied with this sentence, he did not intervene. It emerged during the hearing that warnings were the standard sentence for crimes committed by warders at Westville Prison - no matter how serious these crimes happened to be. Commenting on Sibiya's apparent inability to take positive action to prevent these abuses, Advocate Soni stated:

"All these things pass before your eyes but like a spectator, you do nothing to stop them." 56

On 21 February 2002, senior warder at the Westville Prison Rabson Hlabisa testified. He alleged that on one occasion during December 2001, the head of the Medium C section at Westville Prison, Bongani Ngcobo, was so drunk when reporting for duty that he could hardly stand. He told the commission that Ngcobo regularly came to work drunk and was frequently absent from work. Ngcobo denied the allegations. ${ }^{57}$

On 26 February 2002, Ntombodumo Delubom, who was employed in the Employee Assistance Programme at Westville Prison, testified. She complained that sexism was preventing promotions based on merit within the Correctional Services Department in KwaZulu-Natal. She told the commission that black men with no training were promoted to powerful positions, but that women were ignored. She pointed out that even the head of the female section at the Westville Prison was a male. Managers lacked both leadership and management skills, and were unable to inspire their

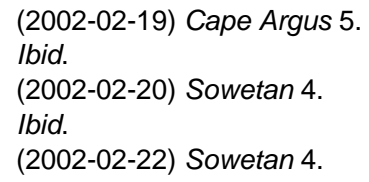


subordinates. Supervisors were rigid and resistant to change. Supervisors were also guilty of favouritism, and there was a tendency for them to cover up disciplinary infractions by their family and friends. This favouritism went hand in hand with racism, with supervisors always favouring employees from their own racial or ethnic group. ${ }^{58}$

Further sensational reports appeared in the press on 28 February 2002. It was reported that the panel-beating workshop at the Westville Prison might have been used to "doctor" stolen vehicles. The chief investigator for the commission, Advocate Jerome Brauns SC, described the following startling allegation that had been made to the commission:

'We've been told that prisoners have been given 'shopping lists' of desirable vehicles and then let out for the night by corrupt officials ... They return with stolen cars, and the chassis and engine numbers are doctored in the prison workshop while the cars are given a respray prior to resale. These are just some of the allegations we've had, but hard evidence is difficult to come by. We've been given the names of some of some of those allegedly involved, but they, of course, deny all knowledge. Intimidation is very high in these circles and people will talk to us in confidence, but are afraid to speak on the record." 59

On 5 March 2002, evidence was led before the commission in relation to the employment of Thembi Zulu, the wife of Innocent Zulu who was head of functional services of the Correctional Services Department in KwaZuluNatal. It was alleged that Innocent Zulu had arranged for the transfer of his wife (who was also a member of the Correctional Services Department) from the Stanger Prison to the Westville Prison. It was irregular for a husband to sign the transfer form of his own wife. Furthermore, according to the evidence, Thembi Zulu was not on the shortlist of applicants for the Westville position, and there was doubt as to whether she was ever stationed at the Stanger Prison. The only time Thembi Zulu was seen at the Stanger Prison was on the day of her "transfer" to Westville Prison. On that day, she arrived at the Stanger Prison in a car driven by her husband, and her name appeared on the prison register for that day; her name did not, however, appear on the duty list for that day. On the following day, it was recorded that she was absent on sick leave, after which it was recorded that she had been transferred to Westville Prison. ${ }^{60}$ It then emerged that Thembi Zulu had a previous criminal conviction for theft, and was ineligible to hold a post in any government department. However, the provincial head of human resources for the Department of Correctional Services in KwaZulu-Natal, Nhlanhla Ndumo, gave evidence that it was accepted policy to employ persons with minor criminal convictions. He stated that the policy did not exist in written form, but had been agreed upon by prison officials at a seminar. ${ }^{61}$ Evidence was then put forward about a "letter of condonation" that had been written on behalf of Thembi Zulu, paving the way for her appointment. Innocent Zulu admitted that he had instructed a prison official,

\footnotetext{
(2002-02-27) Daily News 2.

(2002-02-28) Mail and Guardian 33.

(2002-03-06) Sowetan 4.

(2002-03-08) Daily News 2.
} 
Ronnie Erasmus, to write the letter of condonation, which was then signed by the provincial commissioner of Correctional Services, Thembi Kgosidinsi, who was working in the same office as Innocent Zulu. ${ }^{62}$

A few weeks later, yet more sensational details of evidence presented to the commission appeared in the press. On 26 March 2002, it was revealed that the head of security at the Westville Prison, Tyron Baker, was the official who had been nicknamed "Mr Untouchable" by the press. One of Baker's alleged victims, Mrs Ray Miller, gave evidence. She had spent 13 months in prison awaiting trial on charges of fraud, and alleged that she had paid R6 000 into Baker's bank account after he had threatened that he could make her life in prison "either comfortable or terrible". ${ }^{63}$ She alleged further that Baker had asked her for R3 000, which she had paid, before he would allow her to be taken to hospital outside prison. Baker told the commission he had a problem testifying, since he was facing criminal charges and a departmental inquiry concerning the matter before the commission. ${ }^{64}$

On 4 April 2002, prison officer Winston Naidoo gave evidence. He alleged that he, together with a colleague by the name of Shabalala, had been bribed to ensure preferential treatment of a woman prisoner, Neethie Naidoo. Neethie Naidoo had been convicted of involvement in a cash-intransit heist, and had been sentenced to three years correctional supervision. Winston Naidoo alleged that Neethie Naidoo's husband, Yegan Naidoo, was a friend of a certain "Vishnu", who allegedly supplied mandrax tablets to Innocent Zulu, the provincial correctional officer for functional services. Yegan Naidoo offered to pay a substantial bribe to ensure that his wife was given easy clerical work for her correctional supervision. Zulu allegedly urged Winston Naidoo to assist Yegan Naidoo. Winston Naidoo and his colleague Shabalala then arranged for Neethie Naidoo to be placed in an administrative capacity at the "Wings of Love" institution during her correctional supervision - for which they were paid R19000 in bribes by Yegan Naidoo. Winston gave evidence that he had accepted a further bribe of R2 000 from Yegan Naidoo in order to arrange the transfer of Neethie Naidoo from Wings of Love to the Chatsworth Secondary School. ${ }^{65}$

\section{Corruption with a nasty ideological twist: "Operation Quiet Storm"}

As disturbing as the instances of alleged corruption referred to above might have been, the South African public was to be shocked to its core by explosive allegations of corruption with a particularly nasty ideological twist. On 20 February 2002, Philemon Ntuli, senior official and spokesman for the Department of Correctional Services in KwaZulu-Natal and a former leader of the Police and Prisons Civil Rights Union (POPCRU), gave evidence. He told the commission of a plan called "Operation Quiet Storm" that was

\footnotetext{
(2002-03-07) Daily News 3

(2002-03-27) Daily News 3.

Ibid.

(2002-04-05) Natal Witness 2.
} 
designed to place appointees of POPCRU in high managerial positions throughout the penal system in KwaZulu-Natal. The aim was to bring about transformation in the operation of the prisons in the province. The plan was originally formulated in 1997 at a meeting in Pietermaritzburg, when it was decided that conservative white officials and their black "lackeys" should be replaced with "progressive" black officials. It was decided that Khulekani Sithole should become the National Commissioner of Correctional Services, and that Maxwell Ntoni should become the KwaZulu-Natal Commissioner of Correctional Services. It was also decided that Nhlanhla Ngubo should become the head of the inspectorate, while Nhlanhla Ndumo should become the personnel officer. According to Ntuli, the implementation of the plan included engaging management in arduous meetings, frustrating management, making demands, taking officials hostage, preventing management from entering their offices, as well as engaging in protest action and go-slows. Ntuli told the commission that the plan had gone horribly wrong, resulting in murders and corruption within the prisons:

"Those who benefited from the plan have betrayed it and entrenched their power, resulting in corruption, nepotism, favouritism, bribery and murders."66

According to Ntuli, ordinary officials were terrified of those in power:

"People are too afraid and intimidated to challenge their actions, no matter how unlawful, irregular or improper. They rule with an iron fist." 67

Immediately after testifying, Ntuli was put into a police protection programme. 68

Just under two months later, on 15 April 2002, Ntuli gave further evidence before the commission. He alleged that managers in key positions in the prisons of the province, including himself, owed their promotions to Operation Quiet Storm. Ntuli alleged that Operation Quiet Storm was a reign of terror orchestrated by Nhlanhla Ndumo, Russel Ngubo and Thami Memela, who were all senior officials in the Department of Correctional Services. At the time of Ntuli's evidence, these officials were in custody facing charges of murder, arising from the death during 1998 of Ernest Nzimande, an Induna at Impendle, as well as charges of the attempted murder of three of Nzimande's companions. Ntuli told the commission:

"I never knew that I was employed by a filthy department. I never knew that one was living at the mercy of certain people." ${ }^{69}$

Ntuli made further allegations of corruption against senior members of the Department of Correctional Services. He told the commission that Durban businessman Mari Mutho had been sentenced to three-and-a-half years' imprisonment but had never spent a day in prison, although he was given a prison number. The matter was investigated by an anti-corruption unit and

\footnotetext{
(2002-02-21) Daily News 3.

Ibid.

(2002-02-27) Daily News 2.

69 (2002-04-16) Natal Witness 1.
} 
referred to Raphepheng Mataka, who was head of human resources at the time, but no action was taken and the case was covered up. Ntuli also claimed that Mataka failed to act when anti-corruption members from Pretoria, after being visited in their hotel by persons wearing balaclavas, hurried back home without completing their work. Ntuli claimed that Mataka was not suitably qualified for the position of deputy commissioner (human resources). Ntuli stated that, according to records, Mataka had a legal qualification, but no relevant experience when he was appointed to this important human resources position. Ntuli told the commission that Mataka had been promoted twice a year, which was against departmental policy. Ntuli also made allegations of nepotism within the department. He claimed that the wife of the former national commissioner, Khulekani Sithole, was appointed by the Department of Home Affairs in exchange for the appointment of the wife of the former Home Affairs Director-General, Albert Mokoena, by Correctional Services. Ntuli claimed further that the head of the Pietermaritzburg female prison, Zodwa Dandile, was involved in the murder of Thuthu Bhengu, the director of provincial human resources - in that she (Dandile) lured Bhengu to the window of her residence by making a hoax phone call. Bhengu was then shot through the window and killed. Ntuli also alleged that Russel Ngubo and Nhlanhla Ndumo had been either directly or indirectly involved in the murder of Bhengu, as she had been investigating allegations of corruption within the Department. Ntuli alleged further that the former commissioner of correctional services in Mpumalanga province, $\mathrm{Mr}$ Zwi Mdletshe, had a falsified matriculation certificate, which he used to gain promotion to the department's head office. He alleged that Mdletshe was promoted to a position in head office although he was not in possession of a diploma or a degree, which was a requirement to occupy such a position. Ntuli alleged further that Lindi Mzimela, the daughter of the former minister of Correctional Services, Dr Sipho Mzimela, had been fraudulently appointed as a warder in the department at the time her father was still in office. He told the commission that Lindi Mzimela was employed as a warder without being in possession of a matriculation certificate when she was still 19 years old. According to Ntuli, it was a requirement that prospective warders be at least 21 years old and in possession of a valid matriculation certificate. ${ }^{70}$ Mataka denied Ntuli's allegations, stating that Ntuli was bitter because he had failed to secure a position in the POPCRU national leadership and a departmental promotional post. ${ }^{71}$

The widespread publication in the nation's press of the shocking details summarised above must have been deeply worrying to the average South African. In an editorial dated 17 April 2002, the Natal Witness commented on the evidence given by Ntuli, inter alia, as follows:

"This testimony indicates that individuals (and possibly party-political) groups have been manipulating the affairs of the prison system in this province for their own ends and calls into question the viability of the KwaZulu-Natal prison system .... It reveals that Popcru had developed a long-term strategy of

70 (2002-04-18) Natal Witness 1; (2002-04-18) Daily News 1; (2002-04-18) Sowetan 4; (200204-21) Sunday Times 5; (2002-04-21) Sunday Tribune 8.

71 (2002-04-19) Natal Witness 3. 
circumventing the principle of accountability to the minister of correctional services and had thereby turned prisons into petty fiefdoms accountable to no one .... The evidence for mismanagement and corruption and for violent criminal behaviour among senior management of the prison is growing, and, because the rot in such institutions starts at the top, it's impossible that this has not affected the running of the prison at every level."72

Approximately a month later, an editorial in the Natal Witness summed up the public mood regarding the shocking evidence presented to the Jali Commission, as follows:

"The revelations of crime and corruption emerging from the Jali Commission investigations get worse and worse. Forging matric certificates is small beer compared to the use of prisoners to commit crimes. And some of those thefts and robberies (complete with 'in-jail-at-the-time' alibis) are in turn eclipsed by the use of prisoners to murder political opponents, or colleagues in the Prisons' Service who don't kowtow to the corrupt ruling clique ... The more one learns about the goings-on, the more obvious it seems that there must be a ruthless clean-up. The buck must stop somewhere; someone must take final responsibility for the web of evil that has been spun in the Correctional Services in this province. Someone must see that the guilty are removed and punished, and that decent officials can begin to rebuild a service whose credibility and reputation have been destroyed from within." 73

The sensational revelations in the press outlined above, which arose from dramatic evidence presented to the Jali Commission and which pointed to extensive corruption in the prisons of KwaZulu-Natal, must have left few South Africans in any doubt that the reputation of the post-apartheid penal system was in tatters. Unfortunately, more sensational revelations were to follow. The media frenzy that surrounded the evidence detailing massive corruption in the Durban-Westville Management Area was to be repeated in relation to evidence concerning the other eight management areas investigated by the commission. Since it is beyond the scope of this article to examine in detail all nine management areas, only one further management area is examined through the lens of the public media. The management area covered in Part 2 of this article is Bloemfontein - in particular, the widespread corruption that was revealed at the Grootvlei Prison.

\section{$4 \quad$ CONCLUSION}

Part 1 of this article has traced the public narrative around the hearings of the Jali Commission of Inquiry into corruption in the South African penal system, held in KwaZulu-Natal in the first half of 2002. Although only allegations at the time, the first shocking details that emerged in the press, of systematic and widespread corruption within the Department of Correctional Services, painted an extremely disturbing picture. It was a picture that was to become seared into the South African public imagination in the years that followed. It is submitted that, among the many elements that must have made this picture particularly worrying to South Africans at the time were the following: the extent of the corruption; its almost "commonplace" acceptance

72 (2002-04-17) Natal Witness 8.

73 (2002-05-11) Natal Witness 6. 
by all involved; the fact that it appeared to have infected the Department of Correctional Services from the very top to the very bottom; the immense suffering clearly caused to powerless and vulnerable individuals; the apparent ease with which corrupt officials and prisoners were able to achieve their corrupt aims; the overall impunity with which corrupt activities were carried out; the twisted political ideology employed by certain corrupt officials to rationalise their activities; and the overall toxic nature of what was clearly a deeply ingrained culture of corruption in the context of a country recovering from decades of oppression while trying to build strong democratic institutions. It is submitted that the Jali Commission of Inquiry may be seen as a "canary in the coal mine"; it was able to detect the corrosive effects of widespread state corruption at a relatively early stage during the post-apartheid period. Part 1 of this article has shown that, from as early as 2002, the dangers of this type of corruption were there for all South Africans to see.

As to the wider implications of the above for more recent commissions of inquiry into the threats posed by corruption in South Africa (such as the ongoing Zondo Commission of Inquiry into State Capture), it is clear that the influence and relevance of such a high-profile public commission of inquiry extends far beyond any recommendations it may make in the legal report published after it has fulfilled its mandate. Such commissions are constituted and operate within a particular milieu, both influencing and influenced by the social, political and economic forces that surround them. This dialectical process is mediated through the public media, which often plays a major role before, during and after the operation of such a commission. ${ }^{74}$ As Raanan Sulitzeanu-Kenan points out, such commissions "whether willingly or not, play a political role by often providing critical information about issues of governance and responsibility, either through the course of their investigation, or in those reports and parts thereof that get publicized". ${ }^{75}$ The "critical information" provided to the South African public by the Jali Commission was not sufficient to completely "cure" the penal system or to prevent massive corruption from emerging within other institutions of state in the years which followed. It is submitted, however, that the public narrative that emerged from the hearings of the commission did indeed serve to stamp out much of the corruption within South African prisons, as well as, at the very least, to prepare the South African public for the long battle against corruption that was to follow and, as noted in the introduction to this article, which is reaching its peak at the time these words are being written.

As stated in the introduction, Part 2 of this article will analyse the public narrative surrounding the hearings of the Jali Commission of Inquiry held in the Free State in 2002. It will also advance further arguments as to why

74 As to the role of the media before the appointment of a commission of inquiry, SulitzeanuKenan notes that the extent to which the media puts pressure on politicians concerning a particular crisis (the "media salience") is central to whether a commission of inquiry will be appointed in the first place. He notes: "Contrary to what could be expected and prescribed, this research suggests that the inherent severity of an issue or event does not directly affect the decision to appoint an inquiry, but is mediated by media salience" (Sulitzeanu-Kenan 2010 BJPS 632).

75 Sulitzeanu-Kenan 2010 BJPS 614. 
commissions of inquiry of this type are useful and important in defending liberal constitutional democracies against existential threats such as that posed by the scourge of corruption. 